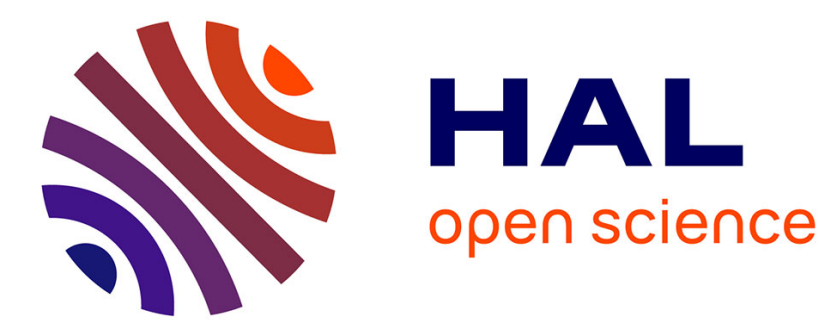

\title{
Will social media strengthen or threaten romantic love?
}

Satu Uusiautti, Kaarina Määttä

\section{To cite this version:}

Satu Uusiautti, Kaarina Määttä. Will social media strengthen or threaten romantic love?. Journal of Social Sciences, 2017, Journal of Social Sciences (COES\&RJ-JSS), 6 (4), pp.709 - 725. 10.25255/jss.2017.6.4.709.725 . hal-01784976

\section{HAL Id: hal-01784976 \\ https://hal.science/hal-01784976}

Submitted on 4 May 2018

HAL is a multi-disciplinary open access archive for the deposit and dissemination of scientific research documents, whether they are published or not. The documents may come from teaching and research institutions in France or abroad, or from public or private research centers.
L'archive ouverte pluridisciplinaire HAL, est destinée au dépôt et à la diffusion de documents scientifiques de niveau recherche, publiés ou non, émanant des établissements d'enseignement et de recherche français ou étrangers, des laboratoires publics ou privés.

\section{다)(1) $(5$}

Distributed under a Creative Commons Attribution - NonCommercial| 4.0 International 
Journal of Social Sciences (COES\&RJ-JSS)

ISSN (E): 2305-9249 ISSN (P): 2305-9494

Publisher: Centre of Excellence for Scientific \& Research Journalism, COES\&RJ LLC

Online Publication Date: $1^{\text {st }}$ October 2017

Online Issue: Volume 6, Number 4, October 2017

https://doi.org/10.25255/jss.2017.6.4.709.725

\title{
Will social media strengthen or threaten romantic love?
}

Satu Uusiautti, Kaarina Määttä

University of Lapland, Faculty of Education, Rovaniemi, Finland

\begin{abstract}
:
The ways we represent our relationships, notice our partners, and let the social media interfere in our romantic relationships have aroused researchers' interest. In this research, the purpose was to analyze, how people who use social media actively perceive the connection between social media and romantic relationships. The research questions set for this study were: (1) What are the rules of self-disclosure that support romantic relationships in social media?; (2) What kinds of benefits do social media provide for romantic relationships?; and (3) What kinds of threats or disadvantages do social media provide for romantic relationships? This was a qualitative research in which the research participants $(\mathrm{N}=25)$ were approached with an online questionnaire that included openended questions. The answers were analyzed with the qualitative content analyzing method. The findings showed that the research participants could name some principles of self-disclosure regarding their romantic relationships in social media and certain benefits as well as harms and threats of social media for a romantic relationship. The findings were further discussed in the light of the elements of love as emotions, love as actions, and love as skills and knowledge that here could be interpreted as "the media literacy of romantic relationships".
\end{abstract}

\section{Keywords:}

social media, romantic relationship, online behavior, love

\section{Citation:}

Uusiautti, Satu; Määttä , Kaarina (2017); Will social media strengthen or threaten romantic love?; Journal of Social Sciences (COES\&RJ-JSS), Vol.6, No.4, pp:709-725; https://doi.org/10.25255/jss.2017.6.4.709.725. 


\section{Introduction}

Social media and social network sites (SNS) are an ordinary part of life: we use the social media to interact and publish widely about our daily lives ${ }^{1}$. The research at hand was conducted in Finland where in 2015, 93\% of people aged 15-55 years had used social media services during the last three months ${ }^{2}$. We asked Finnish university students how they perceived the role of social media from the point of view of romantic relationships.

The way we behave in SNSs vary from people to people, and in recent years, more and more research have been conducted to explain the reasons for our choices, behaviors, and types of agency in SNSs ${ }^{3}$. Kietzmann, Hermkens, McCarthy, and Silvestre ${ }^{4}$ identified seven main elements (identity, conversations, sharing, presence, relationships, reputation, and groups) that explain why people want to spend time and use social media. Research on various phenomena related to romantic relationships have also gained interest among researchers. Wide studies show, for example, how easy it is to find a partner from $\mathrm{SNSs}^{5}$, how romantic relationships develop in $\mathrm{SNSs}^{6}$ and how to announce one's relationship status in $\mathrm{SNSs}^{7}$. However, research highlighting and attempting to hear SNS visitors' own voices regarding their romantic relationships are still scarce.

Our own studies have analyzed love in its various forms ${ }^{8}$ and after having researched people's behavior in $\mathrm{SNSs}^{9,10}$, we wanted to know how people would describe social media from the perspective of romantic relationships. Our objective was to analyze these perceptions in the light of our theory of love ${ }^{11}$ in which we define love as threedimensional human strength: love as emotions, love as actions, and love as skills and knowledge. We wanted to hear their experiences, opinions, and examples, and thus, contribute a qualitatively oriented contribution to this topical scientific discussion.

\section{Research and Theoretical Approaches to Romantic Relationships in Social Media}

There are many ways to approach people's action in SNSs theoretically. Slater ${ }^{12}$ has stated that "attitudinal or behavioral outcomes of media use can be expected to influence selection of and attention to media content" (p. 281) and called the behavior in social media as a reinforcing spiral. Kavanaugh, Reese, Carroll, and Rosson ${ }^{13}$ distinguish two types of social individuals in social media: bridging individuals, who create and organize networks, and bonding individuals, who establish close relationships with others, for example, within a network. Bonding networks provide emotional support and can also be compared to social capital that enhances people's psychological well-being ${ }^{14}$. In addition, social media can make an important channel of establishing and maintaining social relationships and have become an important element of human well-being and happiness as well ${ }^{15,16}$.

To some extent, one's social identity can explain one's social activities in social networks ${ }^{17,18,19}$. Cheung and Lee ${ }^{17}$ have defined that social identity is one of the main elements of intentional social action in online social networks and comprises cognitive, evaluative, and affective components. These components refer to a person's membership in social networks. While cognitive social identity means one's self-awareness of one's membership, evaluative social identity refers to the perceived significance of membership, and affective social identity to the emotional significance of membership. Although Cheung and Lee's ${ }^{17}$ theory describes intentions to use and belong to online social networks in general, the components of social identity may well help understanding the ways people want publish about their romantic relationships in social media, too. 
However, findings regarding romantic relationships and social media are somewhat contradictory. Lea and Spears ${ }^{20}$ have described romantic relationships as a part of social world of media. Their purpose have been to identify situated social interaction that aims to recognize the constructionist dimensions of self, relationships, and technology. They call romantic relationships as socially situated in media. Toma and Choi's ${ }^{21}$ more recent theory of public commitment gives the theoretical foundation an interesting add. Their theory is based on a longitudinal research in which they examined the association between Facebook self-presentations of coupledom and relationship longevity: public relationships commitment increased the couple's likelihood of staying together. Their findings were supported by Lane, Piercy, and $\mathrm{Carr}^{22}$ whose study showed that people who openly publish about their relationship in social medial are more committed and have stronger relationships than those who do not for example reveal their relationship status in Facebook. Results identified However, Northrup and Smith's ${ }^{23}$ research inclined that activity in social media does not correlate with love: according to their findings more activity in social media was connected to less love among couples. One explanation for these differences in the aforementioned studies may be the variety of reasons for human behavior. For example, Fox and Warber $^{24}$ remind that declaring oneself as "In a Relationship" has common social perceptions of the meaning of this status including commitment, intensity, and social response, and may have many kinds of interpersonal and social motives for posting it. Utz and Beukeboom ${ }^{25}$ noted that already people's selfesteem may direct the reasons for activities in SNSs: low self-esteem was connected with tendency to create an idealized picture of relationship happiness and, on the other hand, with SNS jealousy of others' profiles. For some, social media and its network sites provide a way of surveilling their partners ${ }^{26}$ or cheating ${ }^{27,28}$ which are only some of the misuses but simultaneously descriptions of couples activities in social media.

\section{Method}

The purpose of this research was to find out, how people who use social media actively perceive the connection between social media and romantic relationships. The research questions set for this study were

(1) What are the rules of self-disclosure that support romantic relationships in social media?

(2) What kinds of benefits do social media provide for romantic relationships?

(3) What kinds of threats or disadvantages do social media provide for romantic relationships?

This was a qualitative research in which the research participants were approached with an online questionnaire. This was considered a suitable and cost-efficient method of obtaining data.

The participants were university students of educational psychology at a Northern Finnish university. Of 72 students, 25 ( 21 women and 4 men) eventually sent their answers. They were 20-45 years old, and five were singles, eight dating, six co-habiting, and six were married. They were active in social media: 24 reported that they used social media at least once a day and one used it at least once a week.

The questionnaire included two parts. In the first part, the participants' gender, age, relationship status, and activity and familiarity with social media were asked. The second 
part consisted of open-ended questions $(\mathrm{N}=6)$ that followed the research questions. First, the participants were asked to describe their manner of acting in social media and presenting their relationship status there. Their answers were prompted with additional questions inquiring, for example, what kinds of pictures they post or how openly they tell about their lives. The second question inquired the rules set or agreed with their partners or, if they did not have a partner, they could describe their previous relationship or their friends' relationship from this perspective. The next questions concerned the benefits of social media. The participants were also asked to describe an actual situation in social media that was beneficial to the relationship. This could be their own experience or a situation they had witnessed in social media. The two final questions concerned the harms, threats, or other problems social media could pose on a romantic relationship. Here again, the participants were also asked to describe a situation to illustrate this phenomenon. The purpose was to hear the participants' voices ${ }^{29}$ and get information about how the users of social media perceive the influence of social media to romantic relationships.

The descriptions provided by the research participants were extensive. The answers were analyzed by using qualitative content analyzing method ${ }^{30}$. The analysis proceeded from reading the data and categorizing it to themes or categories that emerged from the data. However, the main categories followed the research questions.

When considering the reliability and validity of this research, the basic concepts of a qualitative research evaluation can be used ${ }^{31}$. When it comes to credibility, the attempt is to present a true picture of the phenomenon ${ }^{31}$. That is why the participants' own voices, their experiences and opinions, were obtained. To ensure transferability, we have provided sufficient detail of the research context ${ }^{31}$. University students are somewhat coherent research target and, in this sense, the research could be applied in other settings, too, in a similar manner. Naturally, there might be cultural differences that might cause differences in findings. Dependability refers to the possibility of repeating the study by another researcher ${ }^{31}$. Here, having the data collection performed via an online questionnaire makes it possible to perform the same study again. However, the participants would be different. Openly describing the analyzing process and interpretations are to demonstrate confirmability $^{31}$. In addition, excerpts from their answers were added in Results so that the readers would see how interpretations of the phenomenon were made in this study.

The relevance of data and saturation are also questions that usually are discussed in qualitative research ${ }^{32}$. In our research, the participants' answers were rich and lengthy, and certain themes seemed to emerge from the data so that the answers could be categorized into them. The method of data collection appeared functional, although the percentage of respondents remained low. However, the theme of the research was seen as quite sensible, and therefore, the purpose was to let the participants answer privately and think about the questions in their own time. On the other hand, some of the questions asked might be ones the participants had not even thought about "A good question? I have not thought about it ever." (Participant no. 19) Thus, having time to consider and elaborate the questions was seen important in this research. Participation was voluntary and totally anonymous which meant that the researchers received the answers without any identification information.

\section{Results}

Principles of Self-disclosure

The first purpose of this study was to ask the participants whether they talk about their 
romantic relationships openly in social media and have any rules about it that were agreed with their partners.

What to tell and why?

Majority of the research participants $(\mathrm{N}=15)$ reported that they reveal their social status in social media. Some mentioned only whether they are singles or in a relationship while others also mentioned the name of their actual partner. The reasons for revealing their relationship status in social media varied considerably. Some had not done it before but as they had found new partners, they wanted to do so. Others reported that since their partners were open in social media, they would be as well. Some participants had other kinds of experiences: they had been more open in social media in their past but would now limit their activity and self-disclosure $\mathrm{n}$ various channels of social media.

"My relationship status can be found in Facebook, but only the status is public, not the partner of the relationship.” (Participant no. 11)

"At the beginning of my relationship, my partner and I published our relationship in Facebook but I have been thinking that I would not do it anymore. However, I do not dare to change my relationship status because I do not want to start that flood of questions like oh no, are you not together anymore?" (Participant no. 3)

"In my current relationship, I have also posted by relationship status in Facebook for the first time. I have not done this before." (Participant no. 20)

Only six participants were strict about not revealing their relationship status in social media. The most common reason for this was to consider it such a personal information that should not be shared in public. Quite often the participants described that they would not share any other personal information either, and therefore, the relationship status was merely one of this.

"I tell barely nothing about myself or family there, my name. - - No relationship status, birth date, hobbies, nothing whatsoever." (Participant no. 21)

"We are not friends in Facebook or Instagram." (Participant no. 25)

Singles did not necessarily want to emphasize their status, and thus had decided not to post their relationships status. There were also other situations in which the decision was made by thinking about the audience in social media. Such situation could occur if your connections in social media did not know, for example, about your sexuality. These notions show that already the little piece of information, and whether you reveal it or not, tells not only about your personal behavior and agency but also about your network in social media, too.

"In Facebook, I have hidden the information that I am interested just in my own gender. Both in there and in Instagram, I have people who could resent that." (Participant no. 7)

4.1.2 Differences between spouses

There were other solutions, too, that were not exactly univocal. Someone had decided to 
delete the relationship status information even though was still in the same relationship. In addition, the relationship could be presented in pictures but was otherwise hidden. There were also cases where partners did not agree about the way relationship statuses were revealed in social media.

"I do not bring out my relationship status in social media at all because in my opinion, it is personal. My partner and I, we do have pictures of us there but I never highlight our relationship." (Participant no. 22)

"I try to present myself truthfully, I do not want to create too much 'glitter' in my life. - My partner and I have quite different views on how to use social media, after spending years and years together, [my partner, gender not known] does not want make the relationship status public. - - or publish - - pictures of us together. - - [my partner] publishes it like doing it alone (e.g., hiking, snow mobiling, going to movies etc.). I thus feel being hidden and it causes mistrust, why it is like this. I never get a direct answer to this topic." (Participant no. 17)

In general, participants reported that they used social media actively in their lives, on daily basis. Still relatively many of them were careful and conscious of their behavior in social media and told that they usually ask for permission to publish pictures about their partners. Others had limited their audiences in social media, so that only the closest friends or family members could see their pictures and other postings.

Agreeing about basics

When discussing rules in general, some participants thought that certain rules could be set and agreed with partners. They had not made them but thought that it would be beneficial or that people living in a relationship should think about setting some shared rules.

"We have tried - - but have not reached consensus. I was offended by my husband's deep and flirting chats with his colleague. It came out when all of a sudden, he started to like this woman's pictures who was unfamiliar to me." (Participant no. 16)

"If you are in a relationship and one or both use social media, then of course, you have to agree what you publish and share and with whom." (Participant no. 22)

When thinking about rules in social media especially from the perspective of their romantic relationships, the participants quite openly described even painful experiences. Since social media is a natural part of people's lives nowadays, many features that occur in face-to-face lives too have their place in virtual social media lives.

“There is not much jealousy or if you like other boys' or girls' pictures or comment pictures that is ok. You can be friends that are the opposite sex and you have send private messages to them but within the limits that you could show the messages to your spouse if needed." (Participant no. 12)

Altogether five participants mentioned that they had discussed with their partners about how to behave in social media so that it does not offend their romantic relationship. These rules concerned sharing of pictures and contents of postings but also cheating. 
"We have agreed about the rules of the game. We have agreed what and to whom we talk about ourselves via social media." (Participant no. 10)

"First of all, none of us is allowed to visit any dating applications, e.g., Tinder. I also mentioned it to my boyfriend when he used to comment his friends' pictures with a smiley face with heart-shaped eyes that I would not tolerate that when we are in a relationship. - We also think that flirting in social media is cheating or at least disrespectful toward the other, so we have strict limits in that." (Participant no. 21)

In all, when it came to specific rules according to which the partners should behave or that they had agreed, the variation among the research participants was great. Most of the participants $(\mathrm{N}=18)$ had not agreed any rules or had not perceived it necessary. Many of them answered shortly but others described that if you are in a relationship, the expectation is to behave respectfully and truthfully toward your partner.

"Of course, I expect that my spouse publishes about me with a good taste and appreciating me.” (Participant no. 6)

"We have not agreed any rules for how to use social media. For example, it is difficult to imagine how cheating on your partner in social media would differ from other kind of cheating." (Participant no. 14)

Benefits of social media for a romantic relationship

The research participants were asked to describe what kinds of benefits they thought that social media would have on romantic relationships. Relatively many of them started first by writing that they had never thought about this-mainly just negative sides. However, certain benefits could be found that were categorized into five main categories. Eventually, many of them came up with several benefits and here we have categorized them according to times each benefit was mentioned in the data.

Easiness of keeping in touch

The main benefit mentioned in the research participants' answers was the easiness of keeping in touch with the partner. Altogether 14 of them mentioned this. In the modern world, people travel, work, and study not only across Finland but around the world. For the couples, the opportunity be in touch online, share pictures, tell about their days, joys and sorrows, via social media was considered extremely important for their relationship. Being able to communicate instantly makes one feel that the other is not that far away and strengthens the sense of togetherness.

"At the moment, we live in a remote relationship, therefore social media is very important to our relationship. We keep in touch daily, almost all the time, via social media in messenger and by sending pictures to each other." (Participant no. 20)

"Those who have a relationship, social media can be a communication method when they have too much distance to communicate face-to-face. These kinds of situations are, among others, remote relationships or longer trips separately.” (Participant no. 1)

Appreciation

The second main benefit $(\mathrm{N}=12)$ was ways to cherish the relationship, notice the partner, 


\section{Will social media strengthen or threaten romantic love?}

and show appreciation of the relationship. The participants described that their partners compliment them in public. Also thanking the other via social media was seen to strengthen the relationship. Another means of showing appreciation to the relationship was to post pictures together, create their relationship image together.

"It is beneficial to a couple to notice the other in social media too. For example, I have seen that couples change their wedding picture as their profile picture when they have anniversary." (Participant no. 9)

"If you compliment your spouse in social media in public by telling something that shows your appreciation, love, caring, at the same time you show that you are proud of him or her, which feels good." (Participant no. 8)

Other concrete means of showing appreciation to the partner and the relationship in general were mentioned that were quite concrete, as well.

"The man had succeeded in breaking the woman's vase when cleaning. He knew that the vase was important to the woman, and in the group he was desperately asking for help where he could find that vase and buy a new one to replace the broken one. - I believe that the man's behavior was absolutely beneficial for the relationship. - - I also think about surprise parties arranged via social media. - - This is also good for the relationship because noticing the other is important." (Participant no. 4)

Publicity strengthens commitment

Showing the relationship status to others got equally many mentions $(\mathrm{N}=12)$ in the data. This means that the participants considered it beneficial to the relationship if the status was publicly revealed and that the couples actively appeared in the social media as a couple. In the data, this was described as an act of commitment to the relationship telling others that the partners are serious about their relationship. The majority of participants referring to this benefit had also revealed their relationship status in social media (as described in the first results section) but two participants, who had not published their relationship in social media, reported too that "showing off" could be beneficial to the romantic relationship.

"If you have the relationship status 'in a relationship', it is a clear message to others." (Participant no. 4)

"As a spouse, it is nice to be noted or complemented in public in social media by your spouse. In my opinion, social media is not a place for taking care of your romantic relationship, but being a natural part of your spouse's life also there might strengthen the sense of belonging together." (Participant no. 9)

"The relationship may become stronger if both partners want to create contents in social media. Telling about the relationship together strengthens your trust in that we are together and committed to each other." (Participant no. 24)

Easier partner selection

The fourth benefit was not about maintaining the romantic relationship per se, but about finding the partner in social media. Eight participants mentioned this and considered it a 
good place for finding a partner and getting to know him or her. Social media includes plenty of information about people and the participants of this research had noticed that it was possible to learn about the person you are interested in more in social media. There are numerous partner selection theories that may have to be updated to the ear of social media $^{33}$. Partner selection can be based on many overlapping factors but social media offers new ways of finding partners and falling in love: you learn about them in ways and find information that would not necessarily appear otherwise.

"First of all, you can find a relationship via social media. In addition, you can find information about the possible partner, if you are still considering about starting a relationship with him or her." (Participant no. 1)

"Pictures and texts are stored in there. For example, you can 'stalk' a little in Facebook and see what the other has been doing. It can increase topics to discuss together or reveal even bad sides from the other." (Participant no. 5)

Getting closer with the partner

Finally, six research participants mentioned that social media helps finding shared points of interests, hobbies, or friends - they are important to the romantic relationship and its continuity. Finding pleasant activities that you can do together with your spouse strengthen mutual dependency, feeling of belonging together. This way you can also learn new things about your spouse in social media that are beneficial to the relationship.

"We publish holiday pictures and common trips etc. in social media which gives people a positive impression of our relationship and, for example, helps asking others and finding like-minded couples with whom we can do activities together." (Participant no. 23)

"We have participated in a physical exercising group in social media, and been watching the exercising videos always together in certain day of the week." (Participant no. 17)

"By following your partner's postings in social media you learn to know him or her in a more holistic manner and familiarize with his or her thoughts and values from another perspective. For example, writing can bring out totally new sides from some people." (Participant no. 13)

There were also other benefits that were mentioned by one or few research participants. For example, defending the partner in social media was considered beneficial and an act of love. In addition, two participants reported that social media provided better chances to self-disclosure: it was easier to tell some things about yourself or you just happen to reveal information via social media to your partner that you would not necessarily say or that would not come out otherwise.

\section{Threats and harms of social media to a romantic relationship}

When thinking about the harmfulness of social media to a romantic relationship, the research participants' descriptions could be categorized into five themes.

Time consuming

The most commonly mentioned problem was that social media takes time from the relationship $(\mathrm{N}=15)$. This very fact has been showed in other studies, too ${ }^{34}$. Even though 
the participants appreciated the easiness of communicating with the spouse with the help of social media, they also had noticed that when they were together, their attention still was turned into Facebook, Snapchat, Instagram, Twitter, and other applications of social media. In this sense, social media can interrupt interaction and attention, and alienate partners from each other.

"I would think that the primary threat of social media to a romantic relationship is that people spend too much time there and do not focus on living their lives in this moment now. What is it there in social media that is more important than the actual people next to you? NOTHING.” (Participant no. 19)

"Too much time in social media takes away time to spend with your partner. As if life was lived in the internet and you share postings about a perfect romantic relationship while in reality, your partner would like to have attention from his or her social-media-addicted partner." (Participant no. 1)

\section{Cheating}

Relatively many of the participants $(\mathrm{N}=9)$ discussed cheating in social media. There were many perspectives to it. While some mentioned that it was easy to get to know interesting people in social media and interact in a way that would be called cheating, others had noted that social media could also be a good place to maintain an affair. In addition, the limits of cheating were discussed in the data. The participants asked to which extent it would be appropriate to "like" or comment postings and pictures from other people, and what kind of flirting is acceptable or unacceptable.

"The definition of cheating in social media, especially. Where do you draw the line? I think emotional cheating is worse than physical cheating." (Participant no. 15)

"There are people who visit dating sites although they are in a relationship.- - It is problematic to the relationship, because why to be in that site or the application where the purpose is to find romantic company if you already have it?" (Participant no. 20)

"The wife had talked with her lover in messenger and forgot her laptop open when going to the grocery store. The husband saw the messages and when the wife came back from the store, she had to admit her affair." (Participant no. 17)

\section{Misunderstandings}

In social media, your primary communication method is writing. However, people differ in their writing skills and abilities to interpret other's writings. Therefore, misunderstandings happen also between partners of a romantic relationship, which was noted by seven research participants. Sometimes misunderstandings took place when a partner misinterpreted the other's action in social media and could feel, for example, jealous or otherwise offended.

"Misunderstandings occur easily in social media because communication does not happen face-to-face. It may lead to arguments in a relationship. A funny picture taken during a party night may look something totally different in the partner's eyes." (Participant no. 5) 
"Some pictures or comments may give you a wrong impression of what actually happened or what the other meant. Misunderstandings increase the number of arguments." (Participant no. 12)

False relationship images

The fourth category included descriptions $(\mathrm{N}=7)$ of how couples tend to keep up a certain image of their relationship in social media that became actually harmful to them. The difference here, compared to the benefits of social media when couples positively describe their relationship in social media and thus strengthen their happy feeling about each other, is that the image in social media does not correspond to the real nature of their relationship and thus can even be threatening it. Couples may feel frustrated with their relationship because the expectations and descriptions they post in public do not occur or become fulfilled in real life.

"If you want that things look good in social media but the truth is different. The conflict between real life and social-media-life may cause feelings of insufficiency or disrespect." (Participant no. 8)

"If the purpose of social media is just to keep up the glossy picture of your romantic relationship." (Participant no. 24).

"One couple that I know express their love in Facebook but actually they fight and scold each other all the time." (Participant no. 23)

\section{Public humiliation}

The fifth category was scolding and blaming the partner in social media $(\mathrm{N}=6)$. For some couples, social media represented an arena of arguing, complaining, and showing their frustration. The participants of this research described it humiliating to the partners and annoying to their friends in social media who have to witness these unpleasant conflicts in public.

"Having arguments related to romantic relationships in public in social media is stupid and harmful. The exact point there may be to show the other in a bad light when you are angry.” (Participant no. 4)

"Once I had to witness a couple's public fight on a Facebook page. It was really humiliating for both of them, and they published really sensitive things and private conversations. People take screen shots and spread rumors. Of course, the argument made us too look the couple in a totally different way after that." (Participant no. 12)

The following excerpt from the data shows that the reasons for taking the arguments to social media are manifold: a partner may want to get support from others or showing the problems in public could even be a cry for help. Sometimes arguments appeared also unfair when the partner humiliated or scolded in public could not defend herself or himself, even if reprimands were earned.

"You announce in Facebook to everyone that "my husband had too much on the May 1st party, we had an argument and the police had to come to take him to cool down. I guess we have to break up!' That is disconcerting to a reader, and to the husband, who loses his 
face and opportunity to defend himself. The wife uses power when shouting this to everyone without talking with the husband about their private matter. The wife's behavior is inappropriate as she uses public media." (Participant no. 18)

\section{Discussion: Elements of love in social media}

Social media provides an arena of dating through writing. Although it is not a new invention since people have been searching partners and familiarized with each other through correspondence for ages but now the publicity of writing adds a new element for couples who interact in social media. As the research showed, there are many good sides but also some threats: for example, couples may start building a virtual couple image that does not correspond the reality. On the other hand, partners may learn to know each other more profoundly because they share their thoughts and ideas in social media.

The results of this research show that social media has quite a multidimensional influence in romantic relationships. Since, majority of people participate in social media communities actively, it is expectable that social media is a part of romantic relationships, too. In this research, we wanted to give voice to the participants and hear how they perceived the role and influence of social media. It was possible to find clear categories of how social media could have a positive and a negative influence on romantic relationships. On the positive side, there was first the chance of finding a partner and familiarizing with him or hem in social media. From the perspective of an established romantic relationship, social media made versatile real-time communication easier when partners were far away from each other. Although in our research, the participants emphasized the benefits of social media especially when having to travel and staying geographically far from the spouse, Toma and Choi's ${ }^{35}$ research noted that also for couples being geographically close to each other the quality of mediated communication was connected with relational satisfaction. Based on our data, social media was also a channel of telling others about the relationship and showing commitment, provided opportunities to show appreciation, thankfulness, and love in public, and to find common interests and hobbies $^{21,24}$

Social media had negative influences, too. When too much time is spend in social media, the time is taken from active interaction and shared doings between the partners. Directing the attention to social media instead of the partner or relationship could cause feelings of jealousy, disappointment, and not being appreciated. Social media also provided an easy and tempting arena for cheating. Furthermore, the definition of cheating had to be revisited since cheating may occur differently in social media than in real-life situations. Thirdly, misunderstandings were common in social media: a partner's action could be interpreted in a wrong way, which could lead to unnecessary arguments. Fourthly, social media provided an arena of keeping up a sort of scene. According to our interpretations, couples could fall into pretending that their romantic relationship was happier than what it actually was. In the end, this would be devastating and had a serious negative influence on the relationship. Finally, consideration could became an issue in social media. This study showed that sometimes partners used social media to scold the other and to argue in public. The reason for this behavior could not be defined for sure but one might be that the social media offered a way of seeking other's support and advice in conflict situations.

In all, it was interesting to see the wide scope of actions, emotions, and behaviors that happen in social media and that were linked to the happiness of a romantic relationship. It 
is nothing but obvious how couples should behave or present themselves in social media. Next, we will discuss the findings comparing them with the elements of love as emotions, love as actions, and love as skills and knowledge $\mathrm{e}^{11}$.

Like in the real-life situations, also in social media, our behavior can cause various emotions that are connected to our romantic relationships. On the positive side, relationship-related activity in social media can strengthen admiration, appreciation, respect, and thankfulness toward the partner and relationship. Positive image that also corresponds to the couple's real feelings about their relationship can cause the positive spiral that strengthens the relationship. ${ }^{15,36}$ One of the participants of this study mentioned that posting pictures and posts about happy events with your partner are pleasing to read and supports happiness when you read and watch the pictures later on too (e.g., some social media applications such as Facebook also reminds of old events). In addition, love includes negative feelings, and emotions such as jealous, disappointment, and frustration were also present in social media.

However, emotions often result from certain actions. Here too, certain romantic actions led to increased happiness and satisfaction in the relationship. The partner cannot interpret the other's depth of love and commitment, if they are not shown in action. This concerns social media too: couples can use it as a channel of showing their appreciation and admiration. They can thank their spouse and express how proud they are when they have their spouse on their side. In other surroundings these actions remain often between the partners but in social media they are public. On the other hand, others see the partners' commitment and appreciation of each other but for the partners themselves, it may also be a double-compliment because it is expressed in public. The findings of this research also showed that certain acts function in the opposite way: you can also express you mistrust and despise by scolding your partner in public or find ways of cheating by using social media as the medium. These acts illustrate lack of love or fading love.

Finally, having social media as a part of everyday life requires certain skills. The traditional skills and knowledge of love are interaction skills, problem-solving skills, selfregulation skills, and everyday life management skills ${ }^{11}$. All these were present in social media, too, in a very particular way. As the findings implied, couples need to have abilities to interact with and interpret written messages. In general, this is a very important skill ${ }^{37}$, but becomes highlighted in social media differently because interaction does not happen face-to-face and there is always an audience who adds their own interpretations to the discussion. Second, the couple's ability to solve their problems and regulate their behavior in social media can be a crucial factor to the continuance of their romantic relationship. Public fighting, embarrassment of the spouse, scolding, and also stalking are expressions of lack of self-regulation skills and controlled behavior in public ${ }^{38,39}$.

\section{Conclusion}

Toma and $\mathrm{Choi}^{21}$ listed some self-presentational cues that people use for expressing their romantic relationship in social media. These cues are for example being listed as "in a relationship," posting dyadic photographs, writing on the partner's wall, and at their best, increase satisfaction and commitment to the relationship. Indeed, a good question might be that to what extent we can even separate "real life" and "life in social media" since participation in social media happens in daily basis and is natural to today's people ${ }^{5}$ ? 
However, according to our interpretation, "going Facebook official" is apparently a big, deliberate step for couples ${ }^{24}$. This became clear in our data, too. When the question is not just about oneself but the most sensitive relationship in one's life, it is important to remember that in social media people are under a constant, fast-paced, and real-time influence from other people. And, that the presence of other people becomes easily forgotten and we do not remember to think how our words and acts appear for example in the eyes of our partner's friends and relatives in social media. It seems that the basic rules of behavior are essential when couples enter the arenas of social media ${ }^{9,10}$.

The ability to critically act in social media and analyze the influence of it to the romantic relationship are crucial skills. While we know increasingly about how to find, manage, interpret, and trust in information presented and risks posed in various media-referring to the so-called traditional media literacy ${ }^{12}$ - perhaps we should also think more about the need for "media literacy of romantic relationships". The actual commitment and love are shown in real-life encounters and decisions. However, the research also showed that actions taking place in social media can be equally important from the point of view of romantic relationships: one can express one's love, admiration, and caring-or dissatisfaction, disappointment, jealousy, and frustration. In Sprecher's ${ }^{3}$ research, two thirds of the research participants believed that their behaviors had an influence on the outcome of their romantic relationship.

This research provided us with a multidimensional picture of how social media is connected to romantic relationships and what kinds of pros and cons it might have. Quite much depends on our own actions: what we choose to do, how we present our identities, and how we show our love toward our partners in SNSs-how we create the positively reinforcing spiral of romantic relationships ${ }^{12}$. Eventually, we can be responsible only for our own behavior and therefore, it is always good to ask if this would be something that I would accept or hope my partner doing as well. For the continuity of the romantic relationship, this rule of thumb could be worth even more than its weight in gold.

\section{References}

1. S. Östman."Millasen päivityksen tästä sais?” Elämäjulkaisijuuden kulttuurinen omaksuminen ["What kind of posting this would be?" The cultural adaptation of lifepublishing], University of Turku, Turku, Finland (2015).

2. Finnish people using social media 2015. Helsinki, MTV, Kurio - The Social Media Age(ncy) \& Laurea ammattikorkeakoulu [http://im.mtv.fi/blob/4941078/6c812d65a85598db50814610bd1da47b/suomalaistensosiaalisen-median-kaytto-2015-mtv-white-paper-

data.pdf?utm_campaign=NTF_pdf_Some2015:eimarklupa\&utm_medium=email\&utm_so urce=Eloqua]

3. S. Sprecher. The influence of social networks on romantic relationships: Through the lens of the social network. Personal Relationships, 18(4), 630-644 (2011). [doi: 10.1111/j.1475-6811.2010.01330.x]

4. J. H. Kietzmann, K. Hermkens, I. P. McCarthy, and B. S. Silvestre. Social media? Get serious! Understanding the functional building blocks of social media. Business Horizons, 54(3), 241-251 (2011). [doi: 10.1016/j.bushor.2011.01.005]

5. J. T. Cacioppo, S. Cacioppo, G. C. Gonzaga, E. L. Ogburn, and T. J. VanderWeele. Marital satisfaction and break-ups differ across on-line and off-line meeting venues. 
Proceedings of the National Academy of Sciences of the United States of America, 110(25), 10135-10140 (2013). [doi: 10.1073/pnas.1222447110]

6. J. Fox, K. M. Warber, and D. C. Makstaller. The role of Facebook in romantic relationship development. An exploration of Knapp's relational stage model. Journal of Social and Personal Relationships, 30(6), 771-794 (2013). [doi: 10.1177/0265407512468370]

7. L. Backstrom and J. Kleinberg. Romantic partnerships and the dispersion of social ties: a network analysis of relationship status on Facebook. CSCW'14 Proceedings of the 17th ACM conference on Computer supported cooperative work \& social computing, 831841 (2014). [doi: 10.1145/2531602.2531642]

8. K. Määttä and S. Uusiautti. Many faces of love, Sense Publishers, Rotterdam (2013).

9. S. Uusiautti and K. Määttä. I am no longer alone - How do university students perceive the possibilities of social media? International Journal of Adolescence and Youth, 19(3), 293-305. (2014). [doi: 10.1080/02673843.2014.919600]

10. S. Uusiautti and K. Määttä. If it's ok that your mom can see it, you can publish it- On suitable behavior in social media. British Journal of Education, Society \& Behavioural Science, 4(9), 1184-1202 (2014).

11. K. Määttä and S. Uusiautti. Rakkaus - Tunteita, taitoja, tekoja [Love - emotions, skills, actions], Kirjapaja, Helsinki (2014).

12. M. D. Slater. Reinforcing spirals: the mutual influence of media selectivity and media effects and their impact on individual behavior and social identity. Communication Theory, 17(3), 281-303 (2007). [doi: 10.1111/j.1468-2885.2007.00296.x]

13. A. Kavanaugh, D. Reese, J. Carroll, and M. Rosson. Weak ties in networked communities. Information Society, 21, 119-131 (2005).

14. N. B. Ellison, C. Steinfield, and C. Lampe. The benefits of Facebook 'friends': Social capital and college students' use of online social network sites. Journal of ComputerMediated Communication, 12, 1143-1168 (2007). [doi:10.1111/j.10836101.2007.00367.x]

15. L. R. Saslow, A. Muise, E. A. Impett, and M. Dubin. Can you see how happy we are? Facebook images and relationship satisfaction. Social Psychological and Personality Science, 4, 411-418 (2012). [doi:10.1177/1948550612460059]

16. J. P. Seder and S. Oishi. Intensity of smiling in Facebook photos predicts future life satisfaction. Social Psychological and Personality Science, 3, 407-413 (2012). [doi:10.1177/1948550611424968]

17. C. M. K. Cheung and M. K. O. Lee. A theoretical model of intentional social action in online social networks. Decision Support Systems, 49, 24-30 (2010). [doi:10.1016/j.dss.2009.12.006]

18. K. L. Blair and D. Holmberg. Perceived social network support and well-being in same-sex versus mixed-sex romantic relationships. Journal of Social \& Personal Relationships, 25, 769-791 (2008).

19. C. M. K. Cheung, P.-Y. Chiu, and M. K. O. Lee. Online social networks: Why do students use Facebook? Computers in Human Behavior, 27, 1337-1343 (2011). [doi:10.1016/j.chb.2010.07.028]

20. M. Lea and R. Spears. "Love at first byte? Building personal relationships over computer networks," in Under-studied relationships: Off the beaten track, J. T. Wood \& S. Duck Eds., pp. 197-233, Sage, Thousand Oaks, CA (1995).

21. C. L. Toma, and M. Choi. The couple who Facebooks together, stays together: Facebook self-presentation and relationship longevity among college-aged dating couples. Cyberpsychology, Behavior, and Social Networking, 18(7), 367-372 (2015). 
22. B. L. Lane, C. W. Piercy, and C. T. Carr. Making it Facebook official: The warranting value of online relationship status disclosures on relational characteristics. Computers in Human Behavior, 56, 1-8 (2016). [doi: 10.1016/j.chb.2015.11.016]

23. J. Northrup and J. Smith. Effects of Facebook maintenance behaviors on partners' experience of love. Contemporary Family Therapy, 38(2), 245-253 (2016). [doi: 10.1007/s10591-016-9379-5]

24. J. Fox and K. M. Warber. Romantic relationship development in the age of Facebook: an exploratory study of emerging adults' perceptions, motives, and behaviors. Cyberpsychology, Behavior, and Social Networking, 16(1), 3-7 (2013). [doi:10.1089/cyber.2012.0288]

25. S. Utz and C. J. Beukeboom. The role of social network sites in romantic relationships: effects on jealousy and relationship happiness. Journal of ComputerMediated Communication, 16(4), 511-527 (2011). [doi: 10.1111/j.10836101.2011.01552.x]

26. R. S. Tokunaga. Social networking site or social surveillance site? Understanding the use of interpersonal electronic surveillance in romantic relationships. Computers in Human Behavior, 27(2), 705-713 (2011). [doi:10.1016/j.chb.2010.08.014]

27. R. B. Clayton. The third wheel: the impact of Twitter use on relationship infidelity and divorce. Cyberpsychology, Behavior, and Social Networking, 17(7), 425-430 (2014). [doi: 10.1089/cyber.2013.0570]

28. R. B. Clayton, A. Nagurney, and J. R. Smith. Cheating, breakup, and divorce: is Facebook use to blame? Cyberpsychology, Behavior, and Social Networking, 16(10), 717720 (2013). [doi: 10.1089/cyber.2012.0424]

29. M. Salmela and S. Uusiautti. How to implement the narrative approach in different phases of a positive psychological research? A four-dimensional analysis. International Journal of Research Studies in Psychology, 6(1), 43-55 (2017). doi: 10.5861/ijrsp.2017.1704

30. P. Mayring. Qualitative content analysis. Forum: Qualitative Social Research, 1(2) (2000). [http://www.qualitative-research.net/index.php/fqs/article/view/1089/2385]

31. A. K. Shenton. Strategies for ensuring trustworthiness in qualitative research projects. Education for Information, 22, 63-75 (2004).

32. J. Creswell. W. Research design. Qualitative, quantitative, and mixed methods approaches, Sage, Thousand Oaks, CA (2009).

33. K. Määttä and S. Uusiautti. Who is the one? The difficulty in selecting the partner. International Review of Business and Social Sciences, 1(6), 67-88 (2012).

34. J. M. Grohol. Too much time online: internet addiction or healthy social interactions? CyberPsychology \& Behavior, 2(5), 395-401 (2009). [doi: 10.1089/cpb.1999.2.395]

35. C. L. Toma, and M. Choi. Mobile media matters: media use and relationship satisfaction among geographically close dating couples. CSCW'16 Proceedings of the 19th ACM Conference on Computer-Supported Cooperative Work \& Social Computing, 394-404 (2016). [doi: 10.1145/2818048.2835204]

36. A. Dhir and T. Torsheim. Age and gender differences in photo tagging gratifications. Computers in Human Behavior, 63, 630-638 (2016).

37. K. Määttä and S. Uusiautti. Silence is not golden: review of studies of couple interaction. Communication Studies, $\quad \mathbf{6 4}(1), \quad 33-48 \quad$ (2013). [doi:10.1080/10510974.2012.731467]

38. J. Fox and J. J. Moreland. The dark side of social networking sites: An exploration of the relational and psychological stressors associated with Facebook use and affordances. Computers in Human Behavior, 45, 168-176 (2015). [doi: 10.1016/j.chb.2014.11.083] 
Journal of Social Sciences (COES\&RJ-JSS), 6(4), pp. 709-725

39. K. Scherer. College life on-line: Healthy and unhealthy internet use. Journal of College Student Development, 38, 655-665 (1997).

40. R. Hobbs and R. Frost. Measuring the acquisition of media-literacy skills. Reading Research Quarterly, 38(3), 330-355 (2003). [doi: 10.1598/RRQ.38.3.2] 